\title{
Novel Validated UV Spectroscopic Method for Routine Analysis of Decitabine Drug Substance
}

\author{
Ankit Awasthi, Dheeraj HM, Muddukrishna Badamane Sathyanarayana* \\ Department of Pharmaceutical Quality Assurance, Manipal College of Pharmaceutical Sciences, Manipal Academy of Higher Education, \\ Manipal, Karnataka, INDIA.
}

\begin{abstract}
Objectives: In the proposed study, a basic, novel, protected economic, delicate and cost-effective UV-Spectrophotometric technique for the analysis of Decitabine which is antineoplastic drug. Methods: The created method was approved according to $\mathrm{ICH}$ rules. The decitabine indicated maximum absorption at $221 \mathrm{~nm}$. This strategy can successfully apply for estimation of Decitabine in active pharmaceutical ingredient (API) form for routine examination with UV identification at $221 \mathrm{~nm}$. A Shimadzu UV-Visible spectrophotometer 1800 with $1 \mathrm{~cm}$ quartz cells and Acetonitrile (ACN) as diluent was utilized in this technique. Results: The Developed technique obeyed Beer's-Lambert's law in the conc. of $5.0-15.0 \mathrm{ug} / \mathrm{ml}$, having $R^{2}$ of 0.9993 and $99.82 \% \pm 0.75$ recovery of decitabine was found. Different approval parameters like linearity, accuracy, precision and robustness were performed and were found to be within the limits as per the guidelines of $\mathrm{ICH}$.
\end{abstract}

Key words: Decitabine, UV-spectroscopy, Validated method, ICH guidelines, Beer's Lambert's law, Analysis.

\section{INTRODUCTION}

Decitabine chemically is 4-amino-1-(2deoxy-b-D-erythro-pentofuranosyl)-1, 3,5-triazin-2(1H)-one having molecular weight of 228.08. Decitabine was found to be pyrimidine simple of the nucleoside 2'- deoxycytidine (Figure 1). ${ }^{1-3}$ Mechanism of decitabine shows it has antineoplastic impacts after phosphorylation and direct fuse into DNA and hindrance of DNA methyltransferase, causing hypo methylation of DNA and cellular differentiation or apoptosis. ${ }^{4-6}$ It is designed for the treatment of myelodysplastic (MDS) syndrome. ${ }^{7}$ It was found that decitabine having oral bioavailability (3.9-14\%) which is very low and it has safety profile to the oraldose of $30-240 \mathrm{mg}$ with that of $20 \mathrm{mg} / \mathrm{m}^{2}$ IV administration compared in MDS patients ${ }^{8}$ it was reported that It is unstable in acidic and alkaline condition and metabolized by the enzyme cytidine deaminase which is present in the liver. In impartial $\mathrm{pH}$ it is steady for 7 days at $4^{\circ} \mathrm{C}, 96 \mathrm{hr}$ at $20^{\circ} \mathrm{C}$ and $21 \mathrm{hr}$ at $37^{\circ} \mathrm{C} .{ }^{9,10}$ In basic arrangement, it experiences fast and reversible opening of the 5-azacytosine ring and pursued by irreversible disintegration though, in acidic condition, the glycosidic obligation of aza-nucleoside is separated, which is one of the real foundations for the low oral bioavailability of the decitabine. ${ }^{10}$ Decitabine is somewhat dissolvable in ethanol/water (50/50), methanol/water (50/50) and methanol; sparingly solvent in water and dissolvable in dimethylsulfoxide $(\mathrm{DMSO})^{11}$ literature surveydemonstrates that there are numerous strategies like RP-HPLC ${ }^{12,13}$ and LC-MS ${ }^{14,15}$ for assurance of Decitabine. The Stability demonstrating technique for the estimation of Decitabine is additionally accessible ${ }^{16}$ however from the broad review of the literatures, there is no official method for the determination of the decitabine by UV Spectroscopy has been
Submission Date: 08-04-2020; Revision Date: 17-07-2020; Accepted Date: 07-09-2020

DOI: 10.5530/ijper.54.3s.166 Correspondence:

Dr. Muddukrishna Badamane Sathyanarayana

Department of

Pharmaceutical Quality Assurance, Manipal College of Pharmaceutical Sciences, Manipal Academy of Higher Education, Manipal, Karnataka-576104, INDIA.

Phone: +919483932250

E-mail: krishna.mbs@

manipal.edu

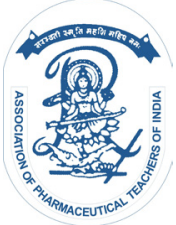

www.ijper.org 
found. According to ICH rules. As UV spectroscopic determination is always first step in any drug analysis so it winds up important to build up an easy, simple, touchy, exact, reproducible method for the estimation of decitabine. Ourprimary aim is to development a method and validation of UV spectrophotometric method for Decitabine bulk as per ICH guideline. ${ }^{17,18}$

\section{MATERIALS AND METHODS Instrumentation}

Shimadzu UV1800 UV-Visible double beam spectrophotometer and one $\mathrm{cm}$ matched quartz cells are used in determination. The glass wares are washed with methanol and water and dried in hot air oven prior to use. The absorption spectra of active pharmaceutical ingredients were carried out in a one $\mathrm{cm}$ quartz cell in the range of $200-400 \mathrm{~nm}$.

\section{Material}

\section{Active pharmaceutical ingredients}

Decitabine was procured as gift sample by sShilpa Medicare Limited, Raichur.

\section{Reagents and Chemicals}

Acetonitrile HPLC Grade (Finer, Ahmedabad), Methanol (Finer, Ahmedabad), Ammonium Acetate (Rankem), Ortho phosphoric acid (Rankem) and Ultra clear water (Siemens, USA).

\section{Methodology}

\section{Ammonium Acetate buffer}

Weigh Accurately about $1.925 \mathrm{gm}$. Ammonium Acetate and dissolved in $500 \mathrm{~mL}$ of water. Ortho phosphoric acid is used for maintaining the $\mathrm{pH}$ to 4.5. Filtration of buffer is carried out in $0.45 \mu \mathrm{m}$ filter.

\section{Diluent}

Mixture ofbuffer and acetonitrile in the ratio of (95:5), sonicate for $5 \mathrm{~min}$ used as a diluent. Afterthat filtration of diluent was carried out through $0.45 \mu \mathrm{m}$ filter.

\section{$\lambda_{\max }$ Determination}

\section{Standard solution}

Weigh accurately About $5.0 \mathrm{mg}$ of decitabine into a $10.0 \mathrm{~mL}$ volumetric flask, add $5.0 \mathrm{~mL}$ of diluent into volumetric flask and then sonicate after that volume was made up to mark with the diluent.

\section{Dilutions}

Acetonitrile was used as diluent for necessary dilution from standard stock solutions to get the concentration of $20 \mu \mathrm{g} / \mathrm{mL}$ of drug sample. $\lambda_{\text {max }}$ of the drug sample were scanned with help of UV-Visible spectrophotometer over the wavelength region of $200-400 \mathrm{~nm}$ against acetonitrile as blank. The absorption curve shows characteristic $\lambda_{\text {max }}$ at $221 \mathrm{~nm}$ for decitabine (Figure 2).

\section{Calibration Curve}

Acetonitrile as a solvent for the preparation of calibration curve at $\lambda_{\max } 221$ using Shimadzu 1800UVVisible spectrophotometer.

\section{Standard stock solution}

Preparation of standard stock sample is done by weighing accurately $5.0 \mathrm{mg}$ of decitabine into $10 \mathrm{ml}$ volumetric flask and dissolve in $3.0 \mathrm{ml}$ mixture of diluent. And volume is made up to the mark with same diluent. Ultra sonication was done to get a clear solution. Then $5.0,7.5,10.0,12.5,15.0, \mu \mathrm{g} / \mathrm{ml}$ were prepared with acetonitrile through serial dilution and absorbance were taken at $\lambda_{\text {max }} 221 \mathrm{~nm}$ against the Acetonitrile as blank. The data obtain from concentration $\mathrm{v} / \mathrm{s}$ absorbance gives standard calibration curve data reported in (Table 1: Concentration and Absorbance of Standard Solution, Figure 3).

\section{Method Validation \\ Linearity and Range}

The linearity was obtained at 5.0 to $15.0 \mu \mathrm{g} / \mathrm{ml}$ concentrations. As per the data obtain plotting the absorbance versus the concentration the standard calibration curve was obtain by linear regression analysis (Table 2). The slope for Decitabine obtained was $\mathrm{y}=$ $0.146 x+0.1474$, the calibration curve was found to be linear within this concentration (The correlation coefficient $\left(R^{2}\right)$ was 0.9993$)$.

\section{Precision}

Precision is evaluated by carrying out five independent sample of $10 \mathrm{ug} / \mathrm{ml}$. If $\%$ RSD is less than $2 \%$ then that method is precise.

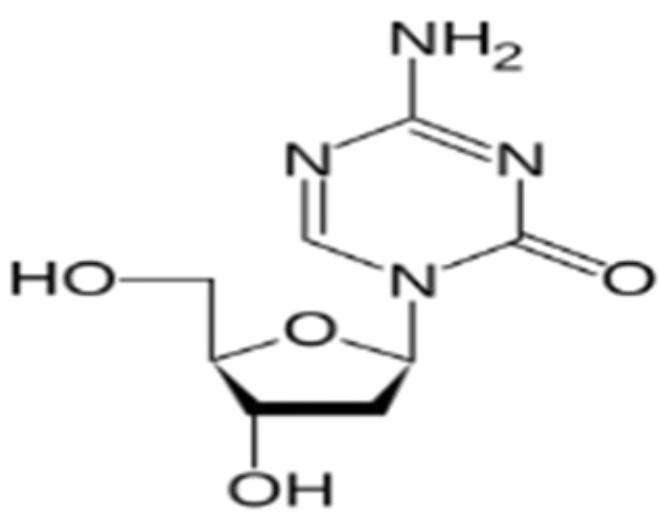

Figure 1: Chemical structure of decitabine. 


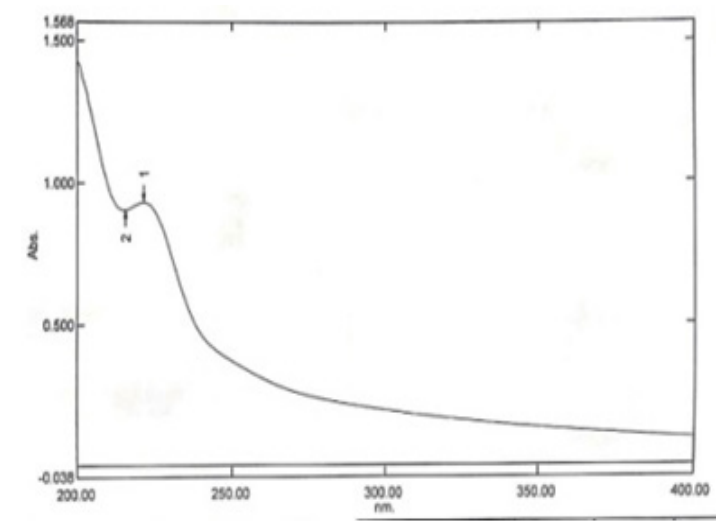

Figure 2: Determination of $\left(\lambda_{\max }\right)$.

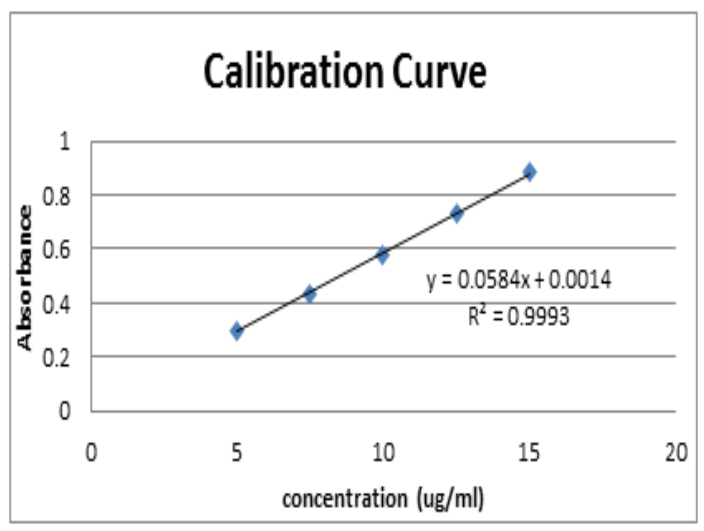

Figure 3: Standard calibration curve.

\begin{tabular}{|c|c|}
$\begin{array}{c}\text { Table 1: Concentration and Absorbance of Standard } \\
\text { Solution. }\end{array}$ \\
\hline conc. & Abs. \\
\hline $5.0 \mathrm{ug} / \mathrm{ml}$ & 0.3011 \\
\hline $7.5 \mathrm{ug} / \mathrm{ml}$ & 0.432 \\
\hline $10.0 \mathrm{ug} / \mathrm{ml}$ & 0.5819 \\
\hline $12.5 \mathrm{ug} / \mathrm{ml}$ & 0.7307 \\
\hline $15.0 \mathrm{ug} / \mathrm{ml}$ & 0.8819 \\
\hline
\end{tabular}

\section{Table 2: Repeatability of $10 \mathrm{ug} / \mathrm{ml}$ drug sample.}

\begin{tabular}{|c|c|}
\hline No. of injections & Abs. \\
\hline 01 & 0.5887 \\
\hline 02 & 0.5871 \\
\hline 03 & 0.5868 \\
\hline 04 & 0.5875 \\
\hline 05 & 0.5865 \\
\hline Average & 0.58732 \\
\hline Std. dev & 0.00086 \\
\hline \%RSD & 0.14567 \\
\hline
\end{tabular}

\begin{tabular}{|c|c|c|c|}
\hline \multicolumn{4}{|c|}{ Table 3: Recovery studies. } \\
\hline & Conc. & Abs. & \%Recovery \\
\hline $75 \%$ & $7.5 \mathrm{ug} / \mathrm{ml}$ & 0.432 & 98.99 \\
\hline $100 \%$ & $10.0 \mathrm{ug} / \mathrm{ml}$ & 0.5819 & 100.00 \\
\hline $125 \%$ & $12.5 \mathrm{ug} / \mathrm{ml}$ & 0.7307 & 100.46 \\
\hline & & Average & 99.82 \\
\hline & & Std Dev. & 0.75 \\
\hline & & $\%$ RSD & 0.75 \\
\hline
\end{tabular}

\begin{tabular}{|c|c|c|c|c|c|c|}
\hline \multicolumn{7}{|c|}{ Table 4: Robustness results. } \\
\hline $\begin{array}{c}\text { Deliberate } \\
\text { Changes }\end{array}$ & Intra-day & Inter-day & $\mathbf{2 2 1} \mathbf{n m}$ & $\mathbf{2 2 5 n m}$ & Analyst 1 & Analyst 2 \\
\hline $\begin{array}{c}\text { Results } \\
\% R S D\end{array}$ & 0.673 & 0.689 & 0.689 & 0.671 & 0.689 & 0.685 \\
\hline
\end{tabular}

\section{Accuracy}

Accuracy of the method can be assessed by recovery studies it is performed in 3 times by standard addition method at 75\%,100\% and 125\% concentration levels. $99.82 \% \pm 0.75$ average recovery was found which shows that method is satisfactory in nature (Table 3).

\section{Robustness}

The analysis was done to check the robustness of method by small change in the method and conditions (Table 4).

\section{RESULTS AND DISCUSSION}

In the present work we have developed and validated an UV spectroscopic technique. The methods were approved according to ICH guidelines. The linearity was $5.0-15.0 \mu \mathrm{g} / \mathrm{ml}$ for UV spectroscopic technique individually, demonstrating the $R^{2}$ of 0.9993 . The UV spectroscopic method was approved for linearity, precision, reproducibility and robustness. Furthermore, $99.82 \% \pm 0.75$ recovery of decitabine was found. All the outcomes were well within the specification according to $\mathrm{ICH}$ rules and thus the proposed method can be 
effectively utilized for the determination of decitabine drug substances for daily and routine analysis.

\section{ACKNOWLEDGEMENT}

The author would like to thank Manipal College of Pharmaceutical Science, MAHE for providing the materials and instruments to conduct this work.

\section{CONFLICT OF INTEREST}

The authors declare no conflict of interest.

\section{ABBREVIATIONS}

ICH: International Conference for Harmonization; UV: Ultra Violate; HPLC: High Performance Liquid Chromatography; RSD: Relative Standard Deviation.

\section{REFERENCES}

1. Wijermans $P$, Lbbert $M$. Epigenetic therapy with Decitabine for myelodysplasia and leukemia. Future Oncology. 2005;1(5):585-91.

2. Ruter $B$, Wijermans $P W$, Lubbert $M$. Superiority of prolonged low-dose azanucleoside administration Results of 5-aza-2'-deoxycytidineretreatment in high-risk myelodysplasia patients. Cancer. 2006;106(8):1744-50.

3. National cancer institute, cancer topics, Dectiabine, www.cancer.gov/ cancertopics/druginfo
4. Schaefer HE, Lubbert M. The hematopathological basis for studying effects of the demethylating agent 5-aza-2'-deoxycytidine (decitabine) in myelodysplasia. Annals of Hematology. 2005;84(1):67-79.

5. Chuang JC, Yoo CB, Kwan JM, Li TW, Liang G, Yang AS, et al. Comparison of biological effects of non-nucleoside DNA methylation inhibitors versus 5-aza2'- deoxycytidine. Molecular Cancer Therapeutics. 2005;4(10):1515-20.

6. www.emedicinehealth.com/drugdecitabine_injection/article_em.html

7. DACOGEN® (decitabine) NDA 021790/S-010 FDA ODAC Briefing Document, Eisai Inc. 2012. http://www.fda.gov/downloads/AdvisoryCommittees/ CommitteesMeetingMaterials/Drugs/OncologicDrugsAdvisoryCommittee/ UCM 290512.pdf

8. Liu D. Recent advances in myelodysplasia: update from $2011 \mathrm{ASH}$ annual meeting. J Hemat Oncolo. 2012;5(S1):A4.

9. Garcia JS, Jain N, Godley AL. An update on the safety and efficacy of decitabine in the treatment of myelodysplastic syndromes. Onco Targets Ther. 2010;3:1-13.

10. Stresemann C, Lyko F. Modes of action of the DNA methyltransferase inhibitors azacytidine and decitabine. Int J Cancer. 2008;123(1):8-13.

11. https://www.accessdata.fda.gov/drugsatfda_docs/label/2006/021790lbl.pdf

12. http://repository-tnmgrmu.ac.in/6827/1/260507917_261330662.pdf

13. Glory H, Teja BB, Ashok KK, Ravindra YR. Stability indicating RP-HPLC Method Development and Validation of Decitabine Drug in Formulation. International Journal of Pharm Tech Research. 2011;3910:237-43.

14. Zhang Y, Sun J, Gao Y, Kong Y, Xu Y, Jia W, et al. An HPLC-MS/MS method for simultaneous determination of decitabine and its valyl prodrug valdecitabine in rat plasma. Chromatogr B Analyt Technol Biomed Life Sci. 2013;917-8.

15. Prakash C, Tushar NM. Fast Analysis of Decitabine using a Solid Core HILIC Column themoscientific. 2013;1-3.

16. Stability indicating RP-HPLC method for the estimation of Decitabine in bulk drug and lipid based Nanoparticleshttps://www.ijpsr.info/docs/ IJPSR14-05-07-100.pdf

17. $\mathrm{ICH}$ Q2A. Guidelines on validation of analytical procedure; Definitions and terminology, Federal Register. 1995;60:11260.

18. ICH Q2B. Guidelines on validation of analytical procedure; Methodology, Federal Register. 1996;60:27464.

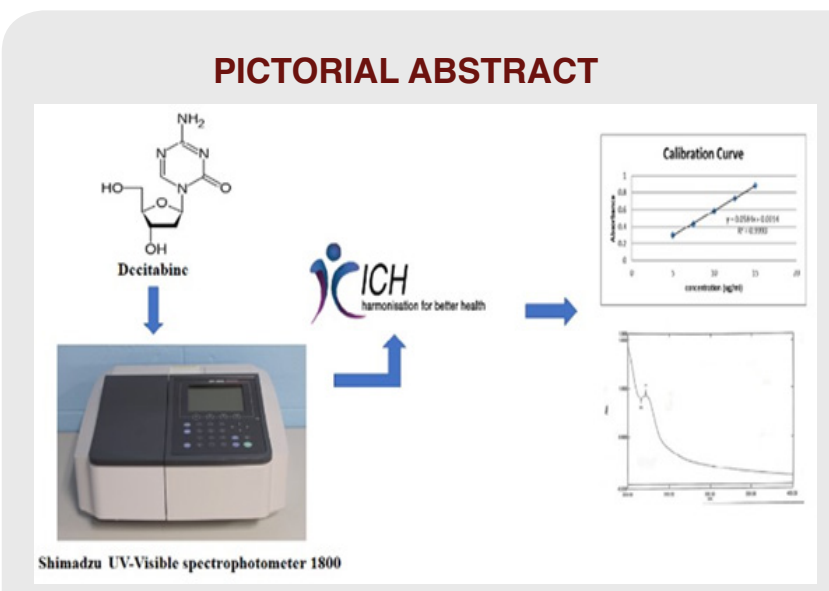

\section{SUMMARY}

As there is no reported method for investigation accessible for the Analysis of Decitabine by UV spectroscopic technique is accounted for yet. Consequently, the depicted UV spectroscopic method for the determination of Decitabine is fast, explicit, simple, delicate, exact and reproducible for determination of decitabine for routine quality control samples.

\section{About Authors}

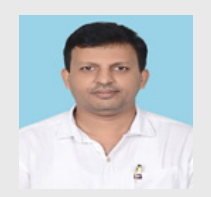

Muddukrishna Badamane Sathyanarayana: Assistant Professor, Senior scale, Department of Pharmaceutical Quality Assurance, Manipal College of Pharmaceutical Sciences, Manipal Academy of Higher Education, Manipal.

Cite this article: Awasthi A, Dheeraj HM, Sathyanarayana MB. Novel Validated UV Spectroscopic Method for Routine Analysis of Decitabine Drug Substance. Indian J of Pharmaceutical Education and Research. 2020;54(3s):s667-s670. 